\title{
Fluid infiltration in the lithospheric mantle beneath the Rio Grande Rift, USA: a fluid-inclusion study
}

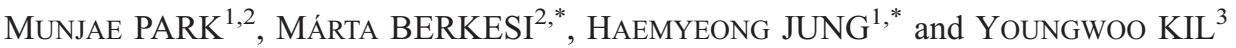 \\ ${ }^{1}$ Tectonophysics Lab, School of Earth and Environmental Sciences, Seoul National University, Seoul, \\ Republic of Korea \\ *Corresponding authors, e-mail: hjung@snu.ac.kr, martaberkesi@caesar.elte.hu \\ ${ }^{2}$ Lithosphere Fluid Research Lab, Eötvös University, Pazmany Peter setany 1/c, 1117 Budapest, Hungary \\ ${ }^{3}$ Department of Energy and Resources Engineering, Chonnam National University, Gwangju, Republic of Korea
}

\begin{abstract}
Spinel-peridotite xenoliths, hosted in alkali basalts ( 15 Ma), were collected from Adam's Diggings in the western margin of the Rio Grande Rift (RGR), New Mexico, USA. We selected five representative spinel-peridotite xenoliths, showing abundant fluid inclusions (FIs). Petrographic observations allowed the distinction of two generations of fluid-inclusion assemblages, both hosted in orthopyroxenes, namely Type-1 (earlier) and Type-2 (later). Both types of fluid inclusions were characterized combining microthermometry, high-resolution Raman micro-spectroscopy, and focused ion beam-scanning electron microscopy. The results of this study indicate that the timing and depth of entrapment, as well as the composition of trapped fluid were different between Type- 1 and Type-2 FIs. The earlier fluid infiltration $(\mathrm{C}-\mathrm{O}-\mathrm{N}-\mathrm{S})$ happened before or during formation of exsolution lamellae and was trapped as Type-1 FIs in the cores of orthopyroxenes, whereas the later fluid infiltration $(\mathrm{C}-\mathrm{O}-\mathrm{H}-\mathrm{S})$ was trapped as Type-2 FIs after the formation of the orthopyroxene porphyroclasts with exsolution lamellae. The two fluid percolation events in the Adam's Diggings peridotites indicate the complexity of mantle fluids around the RGR. During ascent of the xenoliths within a basaltic lava, postentrapment reactions produced magnesite and quartz in Type-1 FIs and magnesite and talc in Type-2 FIs as reaction products of the fluid and its host mineral (orthopyroxene).
\end{abstract}

Key-words: fluid inclusions; mantle xenoliths; fluid percolation; mantle metasomatism; Adam's Diggings; Rio Grande Rift.

\section{Introduction}

During the last decades, a number of studies have shown that the lithospheric mantle can be considered an important reservoir for various volatiles species of the C-O-H-N-S system (Taylor \& Green, 1988; Holloway \& Blank, 1994; Wyllie \& Ryabchikov, 2000; Frezzotti \& Touret, 2014). Major lines of evidence have been the discovery of (1) volatile-bearing minerals such as amphibole and mica (Dawson \& Powell, 1969; Dawson \& Smith, 1982) and/or (2) fluid inclusions in uppermantle xenoliths and peridotite bodies (Török \& De Vivo, 1995; Szabó \& Bodnar, 1996; Andersen \& Neumann, 2001; Frezzotti, 2001; Sachan et al., 2007; Hidas et al., 2010; Berkesi et al., 2012; Frezzotti et al., 2012a). The presence of $\mathrm{C}-\mathrm{O}-\mathrm{H}-\mathrm{N}-\mathrm{S}$ in fluid inclusions hosted by mantle xenoliths is mainly testified by $\mathrm{CO}_{2}$-rich fluid, with minor $\mathrm{H}_{2} \mathrm{O}, \mathrm{N}_{2}, \mathrm{CH}_{4}, \mathrm{CO}$, and $\mathrm{H}_{2} \mathrm{~S}$ components, at either room temperature (Roedder, 1965; Murck et al., 1978; Bergman \& Dubessy, 1984; Pasteris, 1987; Huraiova et al., 1991; Andersen et al., 1995; Yamamoto et al., 2002; Sachan et al., 2007; Frezzotti et al., 2010; Kawamoto et al., 2013; Berkesi et al., 2017) or moderately elevated temperatures (Berkesi et al., 2009; Hidas et al., 2010). Moreover, a few studies documented the presence of Cl-rich fluid inclusions in the lithospheric mantle (Izraeli et al., 2001; Konzett et al., 2014), furtherly revealing the complexity of mantle fluids.

The Rio Grande Rift (RGR) is one of the world's best exposed and most thoroughly studied examples of a continental rift system (Ricketts et al., 2016). Numerous studies have focused on understanding melting and/or metasomatic processes in the mantle by investigating alkali and tholeiitic basalts (Perry et al., 1987), ultrapotassic magmas (Gibson et al., 1993), basaltic melt inclusions (Rowe \& Lassiter, 2009; Rowe et al., 2015), pyroxenite xenoliths (Porreca et al., 2006), and peridotite xenoliths (Smith, 2000; Kil \& Wendlandt, 2004, 2007; Byerly \& Lassiter, 2012, 2015). The latter studies (i.e., peridotite xenoliths) generally used major, trace, and isotopic compositions for tracing and modeling mantle metasomatism. However, fluid-inclusion studies on RGR mantle xenoliths have been lacking so far, despite the fact that fluid/melt inclusions are powerful tools for gaining insight into the nature of cryptic metasomatism (Andersen et al., 1984; Menzies et al., 1987; Belkin \& De Vivo, 1989; 
Schiano et al., 1992; Schiano \& Clocchiatti, 1994; O'Reilly \& Griffin, 2000; Szabó et al., 2009; Hidas et al., 2010; Berkesi et al., 2012; Frezzotti \& Touret, 2014).

Despite the importance of fluid-inclusion study, to our best knowledge, high-density $\mathrm{CO}_{2}$ inclusions were documented only in xenoliths from Kilbourne Hole, located at the rift axis of the RGR (Roedder, 1965). In this paper, we report a detailed study on fluid inclusions hosted by mantle xenoliths from Adam's Diggings (located at the western margin of RGR) using microthermometry, high-resolution Raman micro-spectroscopy, and focused ion beam-scanning electron microscopy (FIB-SEM). Finally, we provide a relationship between Type-1 (earlier) and Type-2 (later) fluid inclusion generations and possible mantle metasomatic event(s). Our results shed light on the complexity of mantle fluids beneath the western margin of RGR.

\section{Geology and sampling}

As one of the world's principal Cenozoic continental rift systems, the RGR extends for more than $1000 \mathrm{~km}$ from Colorado through New Mexico to Mexico (located mostly between the Colorado Plateau and the Great Plains) (Fig. 1). The timing and location of crustal shortening, magmatism, compression, and extension processes in the western USA has been explained by interactions between the North American and Farallon plates (Severinghaus \& Atwater, 1990). During the Laramide orogeny (ca. 80$40 \mathrm{Ma}$ ), shallow subduction resulted in compression, crustal shortening, and uplift of large regions (e.g., the Colorado Plateau) (Dickinson \& Snyder, 1978). Then, Farallon slab delamination ( $\sim 37 \mathrm{Ma})$ and rollback ( $\sim 28 \mathrm{Ma}$ ) processes caused an influx of hot asthenospheric mantle beneath the previously cooled continental lithospheric mantle, and a transition from compressional to extensional tectonics, associated with basaltic volcanisms (Humphreys, 2009; Copeland et al., 2011). Additionally, the subducting Farallon plate hydrated the base of the overlying North American Plate (Humphreys et al., 2003). The development of the RGR is considered to consist of an early rifting (Oligocene to middle Miocene; 37-15 Ma) and a late rifting stage (middle Miocene to Holocene; 15$0 \mathrm{Ma}$ ). According to Kil \& Wendlandt (2007), spinelperidotite xenoliths from the rift shoulder (Adam's Diggings) show strong metasomatic characteristics and evidence of partial melting related to the subducted Farallon oceanic plate. The Farallon slab delamination and rollback processes are considered to have occurred during the early rifting process. During the late rifting, localized alkali basalt magmas erupted in the Adam's Diggings (Fig. 1) brought mantle xenoliths to the surface during the time period between 13 and $6 \mathrm{Ma}$.

From previously collected spinel-peridotite xenoliths (lherzolites and harzburgites) from the Adam's Diggings region beneath the western margin of RGR (Fig. 1), we selected five samples with abundant fluid inclusions (Table 1). These xenoliths were the subject of petrological

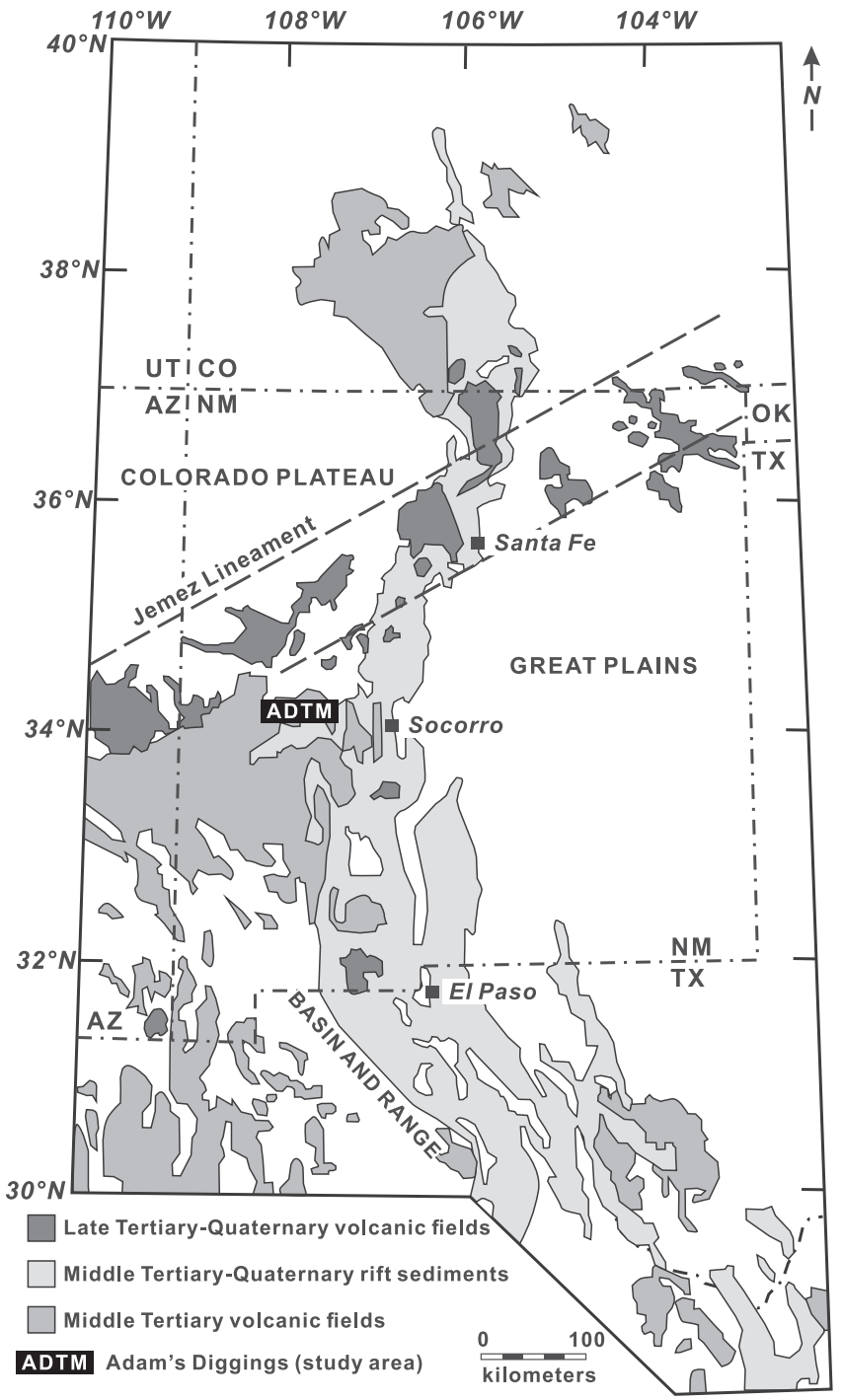

Fig. 1. Simplified geological map in the Rio Grande Rift, New Mexico, USA (modified after Hudson \& Grauch, 2013). The black rectangular box represents the study area (ADTM: Adam's Diggings) on the rift shoulder. The dashed-dotted lines indicate U.S. state boundaries. Dashed lines show the position of the Jemez lineament. Abbreviations: AZ, Arizona; CO, Colorado; NM, New Mexico; OK, Oklahoma; TX, Texas; UT, Utah.

and geochemical studies examining their pressure and temperature conditions (Kil \& Wendlandt, 2004) and metasomatic processes (Kil \& Wendlandt, 2007); however, a detailed fluid-inclusion study was not available. The xenoliths have porphyroclastic textures and have undergone deformation related to the rifting process (Park et al., 2014). They consist of olivine, orthopyroxene, clinopyroxene, and spinel. In addition, xenoliths ADTM18, ADTM27, and ADTM37 contain $0.1,4$, and $0.1 \mathrm{vol} \%$ of phlogopite (Table 1), respectively, as an indicator of modal metasomatism. Exsolution lamellae of clinopyroxene in the orthopyroxene porphyroclasts (Fig. 2a-c) are commonly observed; they were interpreted as having formed prior to xenolith ascent to the surface, indicating a cooling event in the subcontinental lithospheric mantle beneath the western margin of RGR (Kil \& Wendlandt, 2004). A summary of 
Table 1. Modal composition, lithology, texture, equilibrium temperature, pre-eruption depth range, and oxygen fugacity in the studied spinelperidotite xenoliths (Adam's Diggings) from the western margin of the Rio Grande Rift.

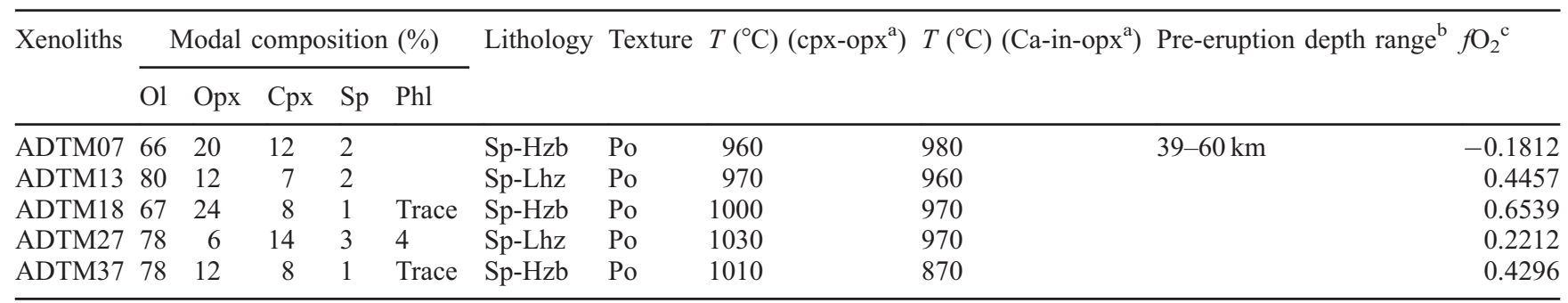

ADTM: Adam's Diggings; Ol: olivine; Opx: orthopyroxene; Cpx: clinopyroxene; Sp: spinel; Phl: phlogopite; Hzb: harzburgite; Lhz: lherzolite; Po: porphyroclastic texture.

${ }^{a}$ Equilibrium temperature (Kil \& Wendlandt, 2004) calculated by two-pyroxene and Ca-in-opx of Brey \& Köhler (1990) at 15 kbar, st. dev. $\pm 16^{\circ} \mathrm{C}$.

${ }^{\mathrm{b}}$ Pre-eruption depth range based on upper mantle structure and textures (Kil \& Wendlandt, 2004).

${ }^{c}$ Oxygen fugacity values calculated by Ballhaus et al. (1991) at $15 \mathrm{kbar}$.

petrographic observations by Kil \& Wendlandt (2004), such as modal composition, lithology, textures, and equilibrium temperatures, is provided in Table 1.

\section{Analytical techniques}

Double-polished thick sections (about $100 \mu \mathrm{m}$ thick) were prepared from the xenoliths, and we selected various fluid inclusions close to the surface $(<10 \mu \mathrm{m})$ for further study.

Microthermometric data were collected using a Linkam THMS600 heating-cooling stage mounted on a Nikon Eclipse LV100PL polarizing microscope at the Lithosphere Fluid Research Lab, Eötvös University, Budapest. For calibration, we used the melting point of $\mathrm{CO}_{2}$ of $-56.6^{\circ} \mathrm{C}$, with an accuracy of measurement of $\pm 0.1{ }^{\circ} \mathrm{C}$. The fluid inclusions were cooled to $-150{ }^{\circ} \mathrm{C}$, beyond having reached complete freezing, and then were slowly heated until visible total homogenization occurred. The density and minimum pressure values of the fluids were estimated using the FLUIDS software package (BULK \& ISOC) (Bakker, 2003).

Micro-Raman analysis was conducted to determine fluid components at the Faculty of Science Research and Instrument Core Facility of Eötvös University, Budapest (ELTE FS-RICF). We used a confocal HORIBA Labram HR (high resolution) 800 spectrometer with Nd-YAG laser $(\lambda=532 \mathrm{~nm})$ excitation, a $1800 \mathrm{~g} / \mathrm{mm}$ optical grating, a 50-200 $\mu \mathrm{m}$ confocal hole, a $2-150 \mathrm{~s}$ acquisition time, and a $100 \times$ objective. The laser spot size (lateral) was measured to be $1.17 \mu \mathrm{m}$, and the depth resolution was $1.73 \mu \mathrm{m}$ (using a $50 \mu \mathrm{m}$ confocal hole and $100 \times$ objective). The laser power was $130 \mathrm{~mW}$ at the source and $\sim 50 \mathrm{~mW}$ at the sample surface. The spectral resolution was $0.7 \mathrm{~cm}^{-1}$ at $1398.5 \mathrm{~cm}^{-1}$ (full width at half maximum of one neon line). We followed the method of Berkesi et al. (2009) for detecting small amounts of water in fluid inclusions. Data evaluation (background fitting and peak fitting using the Gaussian-Lorentzian function) was carried out using LabSpec software. For mineral and fluid identification, the databases by Frezzotti et al. (2012b) as well as RRUFF (rruff.info) were used.
At ELTE FS-RICF, FIB-SEM analysis was also conducted using a FEI QUANTA 3D FIB-SEM apparatus equipped with both secondary and backscattered electron (BSE) detectors, together with a silicon drift energy dispersive spectrometer (EDS). Fluid inclusions with size in the range 5-25 $\mu \mathrm{m}$ and situated less than $5 \mu \mathrm{m}$ from the host-mineral surface were selected for FIB-SEM analysis. The accelerating voltage and current of the electron beam were $20 \mathrm{kV}$ and $10 \mathrm{nA}$, respectively, which allowed major elements having masses ranging from those of Be through $\mathrm{O}$ to $\mathrm{Ba}$ to be analyzed. Identification of daughter phases was based mostly on their morphology on secondaryelectron images and on their brightness on the BSE images, together with examination of EDS spectra. Because of the small size of the daughter phases in the inclusions $(1-5 \mu \mathrm{m})$, the signals detected by EDS were mixed signals, as X-rays from adjacent areas (host phase and/or other daughter minerals) were also recorded. To distinguish the daughter-phase signal from that of the host mineral, EDS control spectra for the host mineral were acquired in the proximity of and from the same depth as the solid phases after each acquisition of daughter-mineral spectrum. The detailed methodology for this technique was described in Berkesi et al. (2012). The size of FIB slices for fluid inclusions was set to $200 \mathrm{~nm}$.

In order to obtain the major-element composition of core orthopyroxenes and enclosed lamellae, electron microprobe analysis was conducted using a wavelengthdispersive JEOL JXA-8100 electron-microprobe at Gyeongsang National University with instrument settings of $15 \mathrm{kV}$ accelerating voltage, $10 \mathrm{nA}$ beam current, $1 \mu \mathrm{m}$ beam size, and $20 \mathrm{~s}$ counting times. Natural standards were used for the analyses and ZAF correction was applied.

Volume percentages of clinopyroxene and spinel lamellae in the lamellae-bearing orthopyroxenes were calculated using one to three representative BSE images for each xenolith (e.g., Fig. 2d). Image resolutions were $254 \mathrm{dpi}$ with a pixel number of $1280 \times 960$. Corel PHOTO-PAINT v.X8 was used to calculate the pixel numbers of the phases. The pixel number of all clinopyroxene, relative to the total pixel number of the 


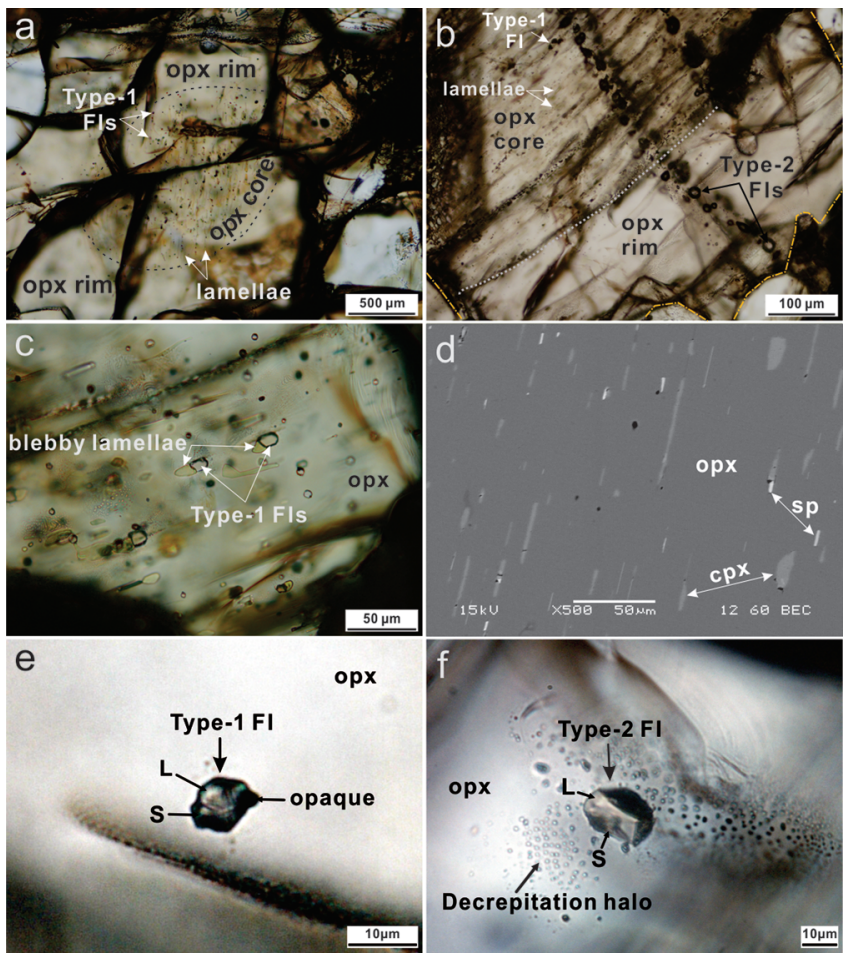

Fig. 2. Photomicrographs (a-c, e, and f) and backscattered electron (BSE) image (d), showing the main petrographic features of fluid inclusions from the studied ADTM xenoliths. (a) Orthopyroxene porphyroclast with lamellae- and inclusion-rich core and lamellaeand inclusion-free rim (xenolith ADTM13). (b) Orthopyroxene porphyroclast with a lamellae-rich and inclusion-rich core and with a lamellae-free and inclusion-free rim, where the entire orthopyroxene grain is crosscut by negative crystal-shaped Type-2 FIs generation (xenolith ADTM27). Dashed-dotted lines denote the edge of the host crystal. (c) Petrographic relationships of the Type-1 FIs (fluid inclusions) and blebby lamellae (likely clinopyroxene) The Type-1 FIs generally occur as individual fluid inclusions; however, in some cases, they appear adherent to a blebby lamella, indicating the presence of fluid during lamellae formation (xenolith ADTM18). (d) BSE image of the lamellae-rich area in the porphyroclastic orthopyroxene core (xenolith ADTM27). (e) Representative image of a negative crystal shape Type-I FI showing three visible phases at room temperature: an opaque solid, a translucent solid (S) and a liquid phase (L) (xenolith ADTM07). (f) Type-2 FI showing negative crystal shape and occurring along healed fractures. This inclusion is decrepitated and contains two phases: solid (S) and liquid (L) at room temperature (xenolith ADTM37). (Online version in color.)

whole image, was taken as the volume percentage of clinopyroxene; the same approach was used for spinel and the core of orthopyroxene.

\section{Fluid-inclusion petrography}

Two generations of fluid inclusions (FIs), all enclosed in orthopyroxene and mostly in deformed porphyroclasts (Fig. 2), were distinguished. Based on our observations, exsolution lamellae are always present in the core of the porphyroclastic orthopyroxenes (Fig. 2a and b), including lamellar spinel (Fig. 2a-d) as well as blebby clinopyroxene (Fig. 2c and d). One fluid-inclusion generation (assemblage) has been identified as either following the orientation of lamellae or adhering to one lamella (Fig. 2c). This fluid-inclusion assemblage (hereafter referred to as Type-1; Fig. 2c and e) is therefore associated to exsolution lamellae, since the lamellae-free rim of the orthopyroxene host does not contain Type-1 FIs. However, numerous lamellae-bearing orthopyroxene porphyroclasts contain no associated fluid inclusions. The size of Type-1 FIs varies between 2 and $10 \mu \mathrm{m}$, and these inclusions dominantly show one (liquid) or two visible phases (liquid and solid) at room temperature (Fig. 2c and e). These inclusions do not exhibit visible signs of stretching and/or decrepitation (Fig. 2c and e). Sometimes, they are associated to an opaque solid phase, adhering to the edge of the individual fluid inclusion (Fig. 2e).

Another type of FI assemblage (hereafter referred to as Type-2, Fig. 2b and f) occurs along healed fractures of orthopyroxene porphyroclasts reaching the edge of the host mineral (Fig. 2b) and crosscutting Type-1 FIs (Fig. $2 b$ ). The size of these inclusions varies within a wide range of 10-100 $\mathrm{mm}$ (Fig. 2f), and the inclusions contain two (liquid, solid) or three (vapor, liquid, solid) phases at room temperature (Fig. 2f). This type of inclusion is typically decrepitated and connected to numerous small fluid inclusions forming halos (Fig. 2f).

\section{Microthermometry}

Microthermometry was conducted on both Type-1 $(n=94)$ and Type-2 $(n=58)$ fluid inclusions (Table S1, freely available online as Supplementary Material linked to this article on the GSW website of the journal: http://eurjmin. geoscienceworld.org). Detailed microthermometric data are reported in Table 2. Upon progressive heating, the first phase transition detected was the melting of a solid phase in the presence of a vapor bubble to liquid. The melting temperatures $\left(T_{\mathrm{m}}\right)$ of this solid phase showed slightly lower ranges in the Type- 1 FIs $\left(-58.0\right.$ to $\left.-57.0^{\circ} \mathrm{C}\right)$ than in the Type-2 FIs $\left(-57.1\right.$ to $-56.8^{\circ} \mathrm{C}$; Table 2$)$. These data indicate the predominance of $\mathrm{CO}_{2}$ in the fluid phase within both types of fluid inclusions. Moreover, the melting-point depression from that of pure $\mathrm{CO}_{2}$ (determined to be $-56.6^{\circ} \mathrm{C}$ ) suggests the presence of minor amounts of other components (e.g., Roedder, 1984; van den Kerkhof, 1988; Frezzotti et al., 2002). After complete melting of the solid phase, only the liquid and the vapor phases were observed together, until further heating resulted in homogenization. Attainment of the homogenization temperature $\left(T_{\mathrm{h}}\right)$ of the liquid and vapor phases always resulted in a liquid phase. Both Type- 1 and Type-2 fluid inclusions showed a wide range of $T_{\mathrm{h}}$ : -42.0 to $-9.5^{\circ} \mathrm{C}$ and 9.6 to $25.5^{\circ} \mathrm{C}$ (Table 2 and Fig. 3), respectively. Density for both types was calculated on the basis of $T_{\mathrm{h}}$ (Table 2), using the equation of state developed by Span \& Wagner (1996), approximated by the pure $\mathrm{CO}_{2}$ system. The calculated $\mathrm{CO}_{2}$ density (for pure $\mathrm{CO}_{2}$ ) for the Type- 1 and Type-2 FIs was $0.98-1.12$ and $0.70-0.86 \mathrm{~g} / \mathrm{cm}^{3}$ (Table 2), respectively. Thus, the $T_{\mathrm{h}}$ range and the calculated $\mathrm{CO}_{2}$ density of the two types of FIs clearly differ from each other without any overlap. 
Table 2. Details of petrography, microthermometry, and Raman micro-spectroscopy of the studied fluid inclusions.

\begin{tabular}{|c|c|c|c|c|c|c|c|c|c|c|}
\hline $\begin{array}{l}\text { Types } \\
\text { (FIA) }\end{array}$ & Xenoliths & $\begin{array}{l}\text { Host } \\
\text { minerals }\end{array}$ & $\begin{array}{l}\text { Size } \\
(\mu \mathrm{m})\end{array}$ & Shape & $\begin{array}{l}\text { Phases } \\
\text { (room } T \text { ) }\end{array}$ & $\begin{array}{l}\text { Fluid } \\
\text { phases }\end{array}$ & $T_{\mathrm{m}}\left({ }^{\circ} \mathrm{C}\right)$ & $T_{\mathrm{h}}\left({ }^{\circ} \mathrm{C}\right)$ & $\begin{array}{l}\rho \\
\left(\mathrm{g} / \mathrm{cm}^{3}\right)^{\mathrm{a}}\end{array}$ & $\begin{array}{l}\text { Solid } \\
\text { phases }\end{array}$ \\
\hline $\begin{array}{l}\text { Type-1 } \\
(n=94)\end{array}$ & $\begin{array}{l}\text { ADTM07 } \\
\text { ADTM13 } \\
\text { ADTM18 } \\
\text { ADTM27 } \\
\text { ADTM37 }\end{array}$ & Opx & $2-10$ & $\begin{array}{c}\text { Negative } \\
\text { crystal } \\
\text { shape }\end{array}$ & $(\mathrm{L}+\mathrm{S})$ & $\mathrm{CO}_{2}-\mathrm{N}_{2}$ & $\begin{array}{l}-57.8 \text { to }-57.3 \\
-58.0 \text { to }-57.4 \\
-57.6 \text { to }-57.0 \\
-58.0 \text { to }-57.2 \\
-57.9 \text { to }-57.0\end{array}$ & $\begin{array}{l}-30.5 \text { to }-16.0 \\
-32.5 \text { to }-11.0 \\
-40.5 \text { to }-19.5 \\
-42.0 \text { to }-15.5 \\
-33.3 \text { to }-9.5\end{array}$ & $\begin{array}{l}1.02-1.08 \\
0.99-1.09 \\
1.03-1.12 \\
1.01-1.12 \\
0.98-1.09\end{array}$ & $\begin{array}{l}\text { Magnesite, } \\
\text { quartz, } \\
\text { sulfide }\end{array}$ \\
\hline
\end{tabular}

$n$ : number of measurements; Opx: orthopyroxene; L: liquid; $\mathrm{S}$ : solid; V: vapor; $T_{\mathrm{m}}$ : melting temperature; $T_{\mathrm{h}}$ : homogenization temperature. ${ }^{a}$ The $\mathrm{CO}_{2}$ density in fluid inclusions calculated by the FLUIDS software package (BULK) (Bakker, 2003).

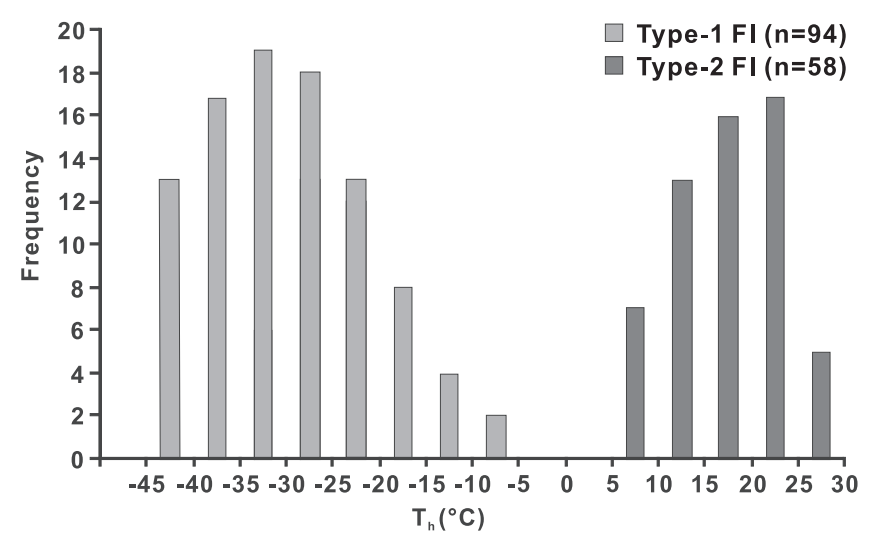

Fig. 3. Histogram showing homogenization temperatures $\left(T_{\mathrm{h}}\right)$ for two distinct $\mathrm{CO}_{2}$-rich fluid-inclusion generations (Type-1 and Type2 FIs). $n$, number of measurement for each fluid inclusion.

\section{Raman microspectrometry}

For the five selected spinel-peridotite xenoliths, microRaman analysis was conducted to identify the compositions of the fluid and solid phases more precisely in each type of fluid inclusions (Type-1, $n=50$; Type-2, $n=50$ ) (Table S1). The results confirmed the data provided by microthermometry, namely, that the Type- 1 and Type- 2 FIs contain dominantly $\mathrm{CO}_{2}$. These two types of fluid inclusions were always detected with a $\mathrm{CO}_{2}$-rich liquid phase (the Fermi diad bands; Raman shift values at $\sim 1281$ and $\sim 1386 \mathrm{~cm}^{-1}$ for Type-1 FIs and $\sim 1282$ and $\sim 1386$ $\mathrm{cm}^{-1}$ for Type-2 FIs) (Fig. 4a and c).

\subsection{Type-1 fluid inclusions}

Due to the attainable spectral resolution of the Raman instrument, we could detect both the nitrogen linked to the fluid phase as well as that in the air (following Berkesi et al., 2017). This was represented by a kind of "doublet" peak in the spectral region around $2330 \mathrm{~cm}^{-1}$ (Fig. 4b). Nitrogen in the air was also detected when measuring the sample off, but close to the inclusion, at the same depth in the sample and with the same parameters as used for the inclusion. The nitrogen peak that was found when measuring only fluid inclusion always appeared at lower wavenumber than that of nitrogen in the air (Fig. 4b): $\sim 2327.3 \mathrm{~cm}^{-1}$ in the fluid and $\sim 2330.7 \mathrm{~cm}^{-1}$ in the air (Fig. 4b).

An opaque solid phase in Type-1 FIs (Fig. 2e) having a Raman peak at $472.5 \mathrm{~cm}^{-1}$ (Fig. 4a) was most likely a sulfide phase. The characteristic peaks of a Mg-carbonate (magnesite) $\left(738.2\right.$ and $\left.1095.5 \mathrm{~cm}^{-1}\right)$ were also found (Fig. 4a).

\subsection{Type-2 fluid inclusions}

For the Type-2 FIs, peaks of dissolved $\mathrm{H}_{2} \mathrm{O}$ in $\mathrm{CO}_{2}$ (at $\sim 3636.1 \mathrm{~cm}^{-1}$ ) are clearly apparent (Fig. 4d). Figure $4 \mathrm{~d}$ also demonstrates that the $\mathrm{H}_{2} \mathrm{O}$ peak intensity increased with increasing temperature, a result similar to that described by Berkesi et al. (2009) for detection of small amounts of $\mathrm{H}_{2} \mathrm{O}$ in $\mathrm{CO}_{2}$-rich FIs. Aside from the dissolved $\mathrm{H}_{2} \mathrm{O}$ peak, the Type-2 FIs also showed the presence of a $\mathrm{OH}$-bearing solid phase, namely talc $\left(\sim 3676.2 \mathrm{~cm}^{-1}\right.$ in Fig. $\left.4 d\right)$. Similar to Type-1 FIs, the presence of magnesite was also observed (peaks at 212.2, 329.2, and $1094.4 \mathrm{~cm}^{-1}$ in Fig. 4c).

\section{Focused ion beam-scanning electron microscopy}

We applied FIB-SEM to observe the morphology and composition of solid phases in unexposed fluid inclusions by using gradational milling steps.

In the Type-1 FIs $(n=6$ from xenoliths ADTM18, 27 and 37; Table S1), an opaque phase (Fig. 2e) with a size of $1-3 \mu \mathrm{m}$ and subhedral shape (Fig. 5a) appeared in bright contrast compared to the host orthopyroxene in BSE images. The EDS analysis indicated that this phase is an Fe (Ni-Cu-Co)-bearing sulfide bleb (Fig. 5a and f). Magnesite and quartz, with sizes of $1-1.5 \mu \mathrm{m}$ and euhedral to subhedral shapes, were also identified (Fig. 5a and b). Generally, minerals in Type-1 FIs are in direct contact with the host orthopyroxene (Fig. 5a and b). 


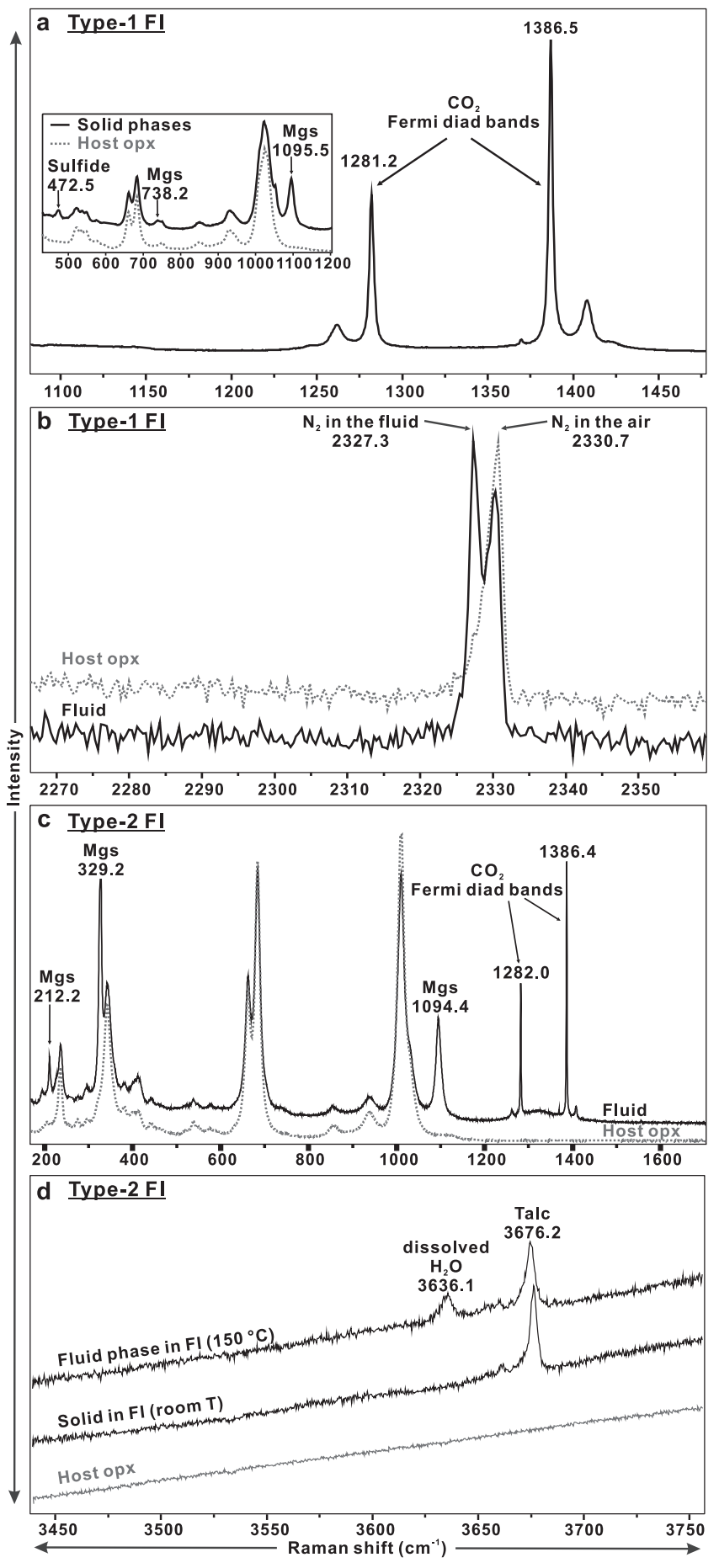

Fig. 4. Representative Raman spectra for orthopyroxene-hosted FIs ( $a$ and b: Type-1; c and d: Type-2). (a) Raman spectra for the Fermi diad bands of $\mathrm{CO}_{2}\left(1281.2\right.$ and $\left.1386.5 \mathrm{~cm}^{-1}\right)$, magnesite (Mgs; 738.2 and $\left.1095.5 \mathrm{~cm}^{-1}\right)$ and sulfide $\left(472.5 \mathrm{~cm}^{-1}\right)$. (b) Raman spectra for the $\mathrm{N}_{2}$ peaks between fluid $\left(2327.3 \mathrm{~cm}^{-1}\right)$ and air $\left(2330.7 \mathrm{~cm}^{-1}\right)$. (c) Raman spectra for the Fermi diad bands of $\mathrm{CO}_{2}$ fluid $\left(1282.0\right.$ and $\left.1386.4 \mathrm{~cm}^{-1}\right)$ and magnesite (Mgs; $1094.4 \mathrm{~cm}^{-1}$ ). (d) Raman spectra showing the band of dissolved $\mathrm{H}_{2} \mathrm{O}$ $\left(3636.1 \mathrm{~cm}^{-1}\right)$ of the fluid phase identified at $150{ }^{\circ} \mathrm{C}$. In addition, presence of talc has been discovered (band at $3676.2 \mathrm{~cm}^{-1}$ ) even in room-temperature measurements. Grey spectra indicate a reference spectrum of the host mineral taken off, but close to the inclusion, applying the same spectroscopic parameters used for the FI beforehand.
Daughter phases from Type-2 FIs ( $n=6$ from xenoliths ADTM18, 27 and 37) (Table S1) differ from those of Type-1 FIs and show higher complexity. Magnesite with euhedral shape and large size (3-4 $\mu \mathrm{m})$ (Fig. 5c and e) was the only mineral found in direct contact with the wall of the host orthopyroxene (Fig. 5c-e). Moreover, the magnesite crystal is covered by a glass layer (Fig. $5 \mathrm{e}$ and $\mathrm{k}$ ), which is similar to the findings of Berkesi et al. (2012). There is also a $3 \mu \mathrm{m}$ size fibrous phase, which is generally attached to magnesite (Fig. 5c and d), and is likely the talc also recognized beforehand by micro-Raman analysis (Fig. 4d). Additionally, a 1-2 $\mu \mathrm{m}$ subhedral Ca- and S-bearing solid phase was detected. Considering the fact that this phase is dark on the BSE image, we suggest that it is a Cabearing sulfate, probably anhydrite (Fig. $5 \mathrm{c}$ and $\mathrm{h}$ ). In addition, a 2-3 $\mathrm{mm}$ subhedral $\mathrm{Fe}-(\mathrm{Ni})$-oxide was also detected (Fig. 5c and i) based on its brightness in the BSE image. These two phases, $\mathrm{Ca}$-sulfate and $\mathrm{Fe}-(\mathrm{Ni})$-oxide, appear together on the wall of fluid inclusions (i.e., surface of orthopyroxene) and are completely covered by magnesite (Fig. 5c). In addition, within Type-2 FI, a thin layer (up to $500 \mathrm{~nm}$ ) with vesicles on its surface are typically present on the inclusion wall and partly cover the daughter minerals (Fig. 5c-e).

\section{Discussion}

As petrographic and compositional characteristics of Type- 1 and Type-2 FIs are similar in all investigated samples (Table 2), we discuss the observations and data obtained with no special attention to the enclosing xenolith.

\subsection{Entrapment of fluid inclusions}

The negative crystal shape of fluid inclusions (Fig. 2) suggests textural equilibrium between the fluid and its host phase (Roedder, 1984; Viti \& Frezzotti, 2000). The development of negative crystal shape through maturation (Bodnar et al., 1989) likely takes a longer period of time than the duration of transport of the xenoliths from the upper mantle to the surface (Roedder, 1984; Szabó \& Bodnar, 1996; Dégi et al., 2009). Moreover, the rapid pressure change during uplift does not favor the formation of negative crystal morphology (Bodnar et al., 1989). Thus, the possibility of the entrapment of the studied fluid inclusions by alkali basalt during transport to the surface is unlikely.

Although both FI types can be regarded as having been entrapped originally at mantle depth, on the basis of their petrographic features, using the terminology and logic of Roedder (1984) and Van den Kerkhof \& Hein (2001), Type-1 FIs seem to have better preserved their original fluid - on the basis of their high density (between 0.98 and $1.12 \mathrm{~g} / \mathrm{cm}^{3}$; Table 2) and the absence of petrographic features indicative of significant re-equilibration. In contrast, Type-2 FIs have $\mathrm{CO}_{2}$ densities between 0.70 and $0.86 \mathrm{~g} / \mathrm{cm}^{3}$ (Table 2) and show strong petrographic 

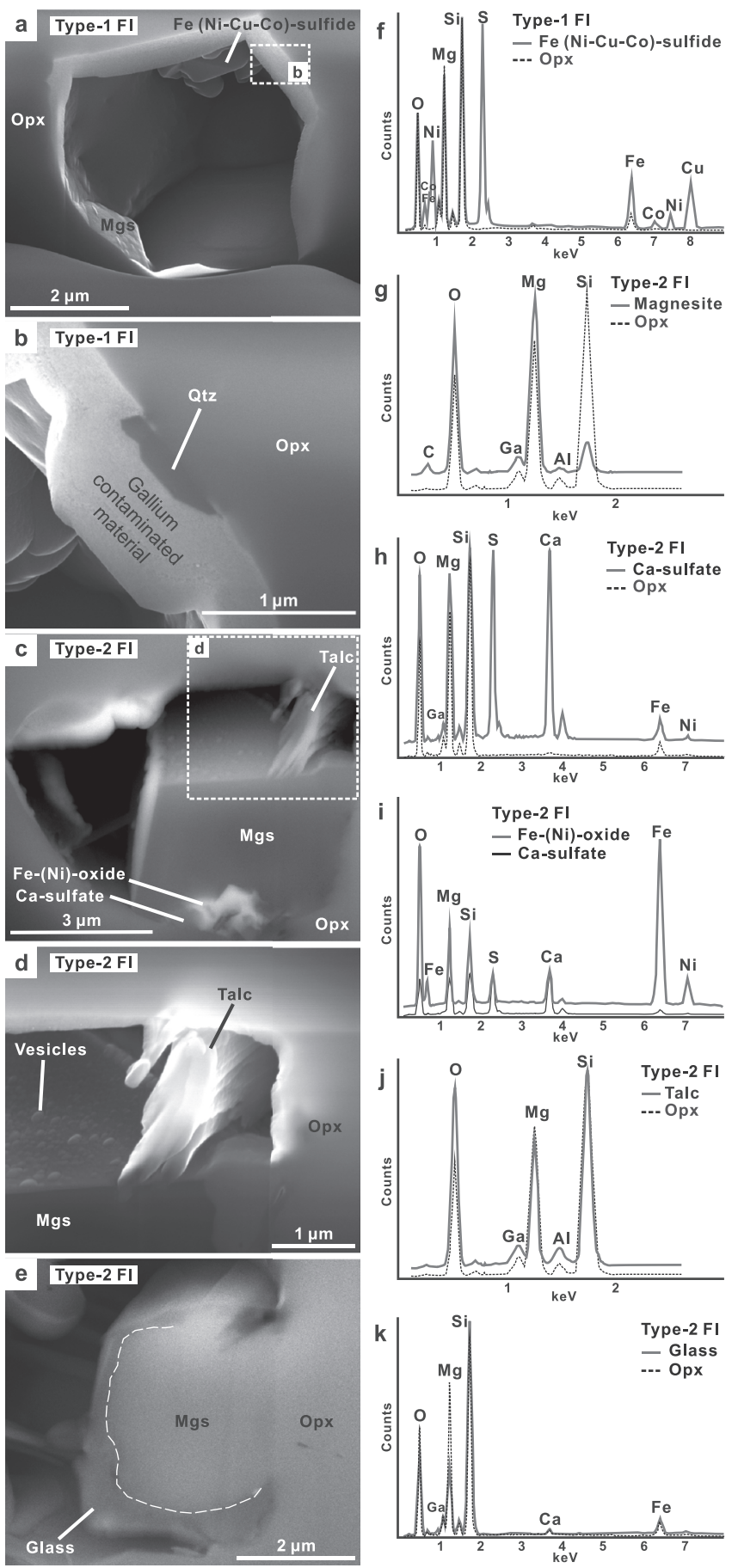

Fig. 5. Representative images and EDS spectra taken during stepwise FIB exposure of the daughter phases in the Type-1 FI (a and b) and Type-2 FI (c-e) orthopyroxene-hosted fluid inclusions. The secondary-electron images of a Type-1 FI (xenolith ADTM27) show (a) $\mathrm{Fe}(\mathrm{Ni}-\mathrm{Cu}-\mathrm{Co})$-sulfide and magnesite and (b) quartz on the wall of a fluid inclusion. (b) Close-up image from the white-dashed rectangular area in (a) after milling procedures. (c) Backscatteredelectron (BSE) image of a Type-2 FI (xenolith ADTM37) showing magnesite, talc, Fe-(Ni)-oxide, and Ca-sulfate. (d) Close-up secondary-electron image of talc, magnesite, and glass vesicles on the magnesite from the white-dashed square in (c). Talc and magnesite are connected to each other. (e) BSE image of a Type-2 FI (xenolith ADTM18) showing a glass layer on magnesite. (f-k) EDS spectra of daughter and step-daughter phases shown in (a-e). evidence for re-equilibration to lower densities by partial fluid leakage (Fig. 2f). Type-2 FIs could have decrepitated more easily because they are larger than Type-1 FIs (2$10 \mu \mathrm{m}$ for Type- 1 and $10-100 \mu \mathrm{m}$ for Type-2; Table 2). A positive correlation between size and appearance of decrepitation as a result of brittle deformation or stretching as a plastic failure in quartz- and olivine-hosted fluid inclusions has been shown experimentally (Hall \& Bodnar, 1989; Wanamaker \& Evans, 1989; Yamamoto et al., 2011; Campione et al., 2015). Petrographic observations also indicate that Type- 1 and Type-2 FIs were trapped at different times, because Type- 2 inclusion trails commonly crosscut Type- 1 inclusions, reaching the edge of the host orthopyroxene (Fig. 2b). Type-1 inclusions thus represent an "older" fluid generation entrapped prior to or during the formation of exsolutions in the core of orthopyroxene, whereas Type- 2 inclusions represents "younger" fluids entrapped after the formation of exsolution lamellae in orthopyroxene porphyroclasts.

\subsection{Temperature estimate for fluid-inclusion entrapment}

The occurrence of exsolution lamellae (of clinopyroxene and spinel) in the core of orthopyroxene porphyroclasts is a common phenomenon in mantle xenoliths beneath the studied area (Fig. 2a-d), indicative of a cooling stage during the evolution of this lithospheric mantle sector (Kil \& Wendlandt, 2004). This is the general explanation for such exsolved minerals in mantle xenoliths (e.g., Bedini et al., 1997; Spengler et al., 2012; Pintér et al., 2015) because the strong $T$-dependence of Ca-isopleths in orthopyroxene (e.g., Gasparik, 2000) requires clinopyroxene lamellae and associated Al-mineral phases (in our case spinel) to be formed during cooling (Spengler et al., 2012).

Exsolution lamellae are formed by two possible genetic mechanisms: (i) nucleation and growth within the host crystal or (ii) spinodal decomposition (McCallister \& Yund, 1977; Putnis, 1992; Sánchez-Muñoz et al., 2016). However, these solid-state mechanisms do not necessarily allow fluid entrapment in the orthopyroxene. We suggest that the entrapment of Type-1 FIs started either before or during the formation of the exsolution lamellae. Type-2 FIs, which are crosscutting the lamellae and Type-1 FIs, were trapped in their host orthopyroxene after the lamellae were formed.

Considering this sequence of events (fluid inclusions and lamellae formation), "paleo" orthopyroxene compositions (before exsolution, $\mathrm{Opx}_{\text {paleo }}$ ) were calculated using the volume of the lamellae relative to their host orthopyroxene (similar to methods described in Bedini et al., 1997). In the studied orthopyroxene porphyroclasts, the obtained ranges are: $96.97-98.04 \pm 0.05 \mathrm{vol} \%$ for orthopyroxene core (where lamellae occur), $1.69-2.37 \pm 0.05 \mathrm{vol} \%$ for clinopyroxene lamellae, and $0.28-0.52 \pm 0.05 \mathrm{vol} \%$ for spinel lamellae (Table 3). Applying the given vol\%, Opx $x_{\text {paleo }}$ compositions show a slight increase in $\mathrm{Al}_{2} \mathrm{O}_{3}, \mathrm{CaO}, \mathrm{Cr}_{2} \mathrm{O}_{3}$, and $\mathrm{Na}_{2} \mathrm{O}$ (Table 3). Owing to the lack of known 
clinopyroxene composition before lamellae formation, it was not possible to apply a two-pyroxene thermometer. Instead, the Ca-in-opx thermometers developed by Brey \& Köhler (1990) and Nimis \& Grütter (2010) were applied, both set at $1.5 \mathrm{GPa}$. As a result, "paleo" temperatures (before exsolution of clinopyroxene and spinel, $T_{\text {paleo }}$ ) as well as "neo" temperatures (after exsolution of clinopyroxene and spinel, $T_{\text {neo }}$ ) were calculated (Table 3 ). The $T_{\text {paleo }}$ values vary between $1056-1094\left( \pm 16^{\circ} \mathrm{C}\right)$ using the method of Brey \& Köhler (1990) and between $1051-1093\left( \pm 25^{\circ} \mathrm{C}\right)$ using the method of Nimis \& Grütter (2010). Values of $T_{\text {neo }}$ are lower, 952-969 $\left( \pm 16^{\circ} \mathrm{C}\right)$ using the method of Brey \& Köhler (1990) and $931-951\left( \pm 25^{\circ} \mathrm{C}\right)$ using the method of Nimis \& Grütter (2010). As a consequence, minimum temperature conditions for Type-1 FI entrapment are determined by $T_{\text {neo }}$. Entrapment temperature for Type-2 can rather be estimated to fall between $T_{\text {neo }}$ and the latest equilibrium temperatures in the xenoliths at mantle depth. The latter one has already been calculated by Kil and Wendtland (2004) using the twopyroxene geothermometer (developed by Brey \& Köhler, 1990; Table 1). On this basis, entrapment temperature for Type- 2 was in the interval between 930 and $1030\left( \pm 16^{\circ} \mathrm{C}\right)$.

\subsection{Type-1 FIs}

Fluids in the Type-1 FIs likely contain small amounts of $\mathrm{N}_{2}$ (because of the low-intensity peak on the Raman spectrum, Fig. 4b) that can be responsible for the $T_{\mathrm{m}}$ melting-point depression (van den Kerkhof, 1988). Highdensity fluid inclusions show that $\mathrm{CO}_{2}$ is common in mantle fluids (Frezzotti et al., 2002, 2010, 2012a; Berkesi et al., 2009, 2012) and that $\mathrm{N}_{2}$ may also be a minor but common component in subcontinental lithospheric uppermantle fluids (Berkesi et al., 2017). These authors calculated $\mathrm{N}_{2}$ concentrations ranging from 0.3 to $1.8 \mathrm{~mol} \%$ in extremely high-density $\left(\geq 1 \mathrm{~g} / \mathrm{cm}^{3}\right)$ fluid inclusions from xenolith sample ADTM27, corresponding to Type-1 FIs of this study. These results are in good agreement with our observations that nitrogen in a free fluid phase at spinel-lherzolite stability conditions may be present as $\mathrm{N}_{2}$ (e.g., Andersen et al., 1995; Berkesi et al., 2017). According to Frost \& McCammon (2008), at spinel-lherzolite stability, the oxygen fugacity is within \pm 2 $\log$ units of the fayalite-magnetite-quartz (FMQ) buffer, consistent with the presence of $\mathrm{N}$ as $\mathrm{N}_{2}$ (and of $\mathrm{H}_{2} \mathrm{O}$ ) in the $\mathrm{H}-\mathrm{N}-\mathrm{O}$ system (Watenphul et al., 2010). In our study, precise $\mathrm{N}_{2}$ contents could not be measured because of the complexity of the solids present within the inclusions (magnesite, quartz, and sulfide; Fig. 5a and b). However, the Raman intensity ratios of the fluid components $\left(\mathrm{CO}_{2}\right.$ and $\mathrm{N}_{2}$ ) suggest similarly low $\mathrm{N}_{2}$ content $(\leq 3 \mathrm{~mol} \%)$ in the studied Type-1 fluid inclusions.

In general, the redox conditions provide the main control on the liberation of $\mathrm{N}_{2}$ from the convecting mantle (Smith et al., 2014) by the oxidation of $\mathrm{NH}^{4+}$ in hydrous silicates (mostly phlogopite) to mobile $\mathrm{N}_{2}$. Previous petrographic observations (Kil \& Wendtland, 2004) documented the occurrence of phlogopite in the ADTM xenoliths (ADTM18, 27, and 37; Table 1); this mineral could be regarded as a source of nitrogen potentially liberated during a precedent heating event, as a consequence of lithosphere attenuation during early rifting (Kil \& Wendtland, 2004). In this scenario, $\mathrm{H}_{2} \mathrm{O}$ is also expected in the fluid phase. It is important to emphasize that the previous existence of $\mathrm{H}_{2} \mathrm{O}$ cannot be excluded even though Type-1 FIs were found to be water-free, because of possible diffusive loss via nano-cracks (e.g., Viti \& Frezzotti, 2000), this even if the inclusion do not show any petrographic evidence of re-equilibration. This point, however, must be clarified by further investigation.

\subsection{Type-2 FIs}

As shown above, the Type- 2 event represents a later-stage fluid infiltration that was trapped after the formation of lamellae in the orthopyroxene porphyroclasts. In contrast to the Type-1 FIs, Type-2 FIs are $\mathrm{H}_{2} \mathrm{O}$-bearing and contain numerous phases (Fig. 5c) such as a silicate glass film (Fig. 5e) covering magnesite, talc, Ca-sulfate (likely anhydrite), and $\mathrm{Fe}-\mathrm{Ni}$ oxide. The presence of talc and sulfate is a common feature in $\mathrm{CO}_{2}-\mathrm{H}_{2} \mathrm{O}$ fluids (Frezzotti et al., 2010).

Silicate glass films in mantle fluid inclusions from the Central Pannonian Basin were previously reported by Berkesi et al. (2012), who concluded that silicate melt components were dissolved in the $\mathrm{H}_{2} \mathrm{O}$-bearing $\mathrm{CO}_{2}$-rich fluid at entrapment. Moreover, various trace elements are considered to be dissolved in $\mathrm{H}_{2} \mathrm{O}$-bearing $\mathrm{CO}_{2}$-rich fluids that formed via silicate (andesitic) melt/volatile immiscibility at high pressure and temperature (Szabó et al., 2009; Hidas et al., 2010). It has also been suggested that, following this phase separation, melt and fluid evolved along different paths and could have migrated separately at upper-mantle depth, interacting with the peridotitic rocks. We infer that Type-2 FIs may originate from such processes, whereby only the separated fluid phase was trapped in the studied rocks. During cooling, probably after eruption of the basaltic host, minor amounts of dissolved silicate melt quenched onto the wall of the inclusion as proposed by Hidas et al. (2010).

\subsection{Possible source of the fluids related to metasomatic evolution}

Previous petrologic and major- and trace-element mineral-chemistry data indicated three metasomatic events beneath Adam's Diggings (referred to as MM1, MM2, and MM3, following Kil \& Wendlandt, 2007). The timing of MM1 (the first enrichment process) is thought to precede the rifting stage (older than $37 \mathrm{Ma}$ ), when the upper mantle beneath the RGR was heterogeneous with MORB- and OIB-type (old subducted slab) mantle components (Frey \& Prinz, 1978; Kyser \& Rison, 1982; Leeman, 1982; Roden et al., 1988). The MM1 event may have been related to K-enriched fluid/melt originating from an old subducted slab (the Farallon plate) and likely precipitated a hydrous mineral (i.e., phlogopite) (Kil \& 


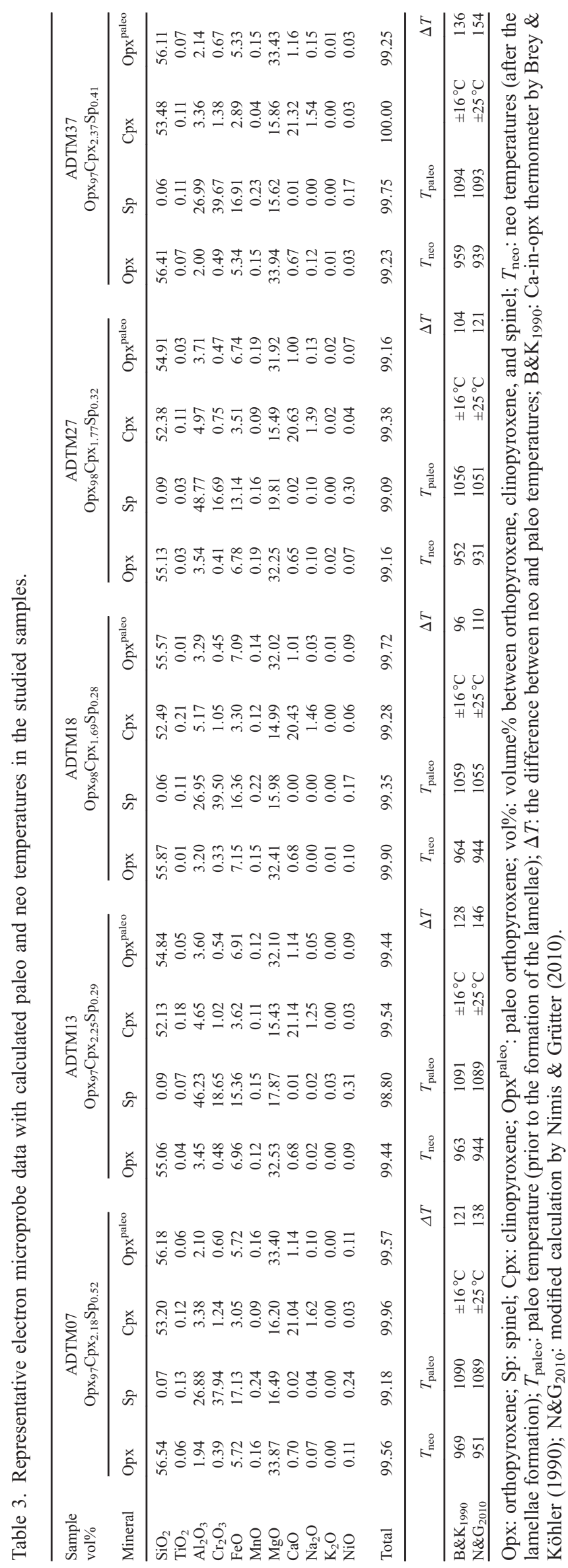

Wendlandt, 2007). This is consistent with the hydration process related to the flat subduction of the Farallon slab (until $40 \mathrm{Ma}$ ) in western North America (Smith et al., 1999; Smith, 2000; Lee, 2005). Regarding our observation that inclusions are hosted in orthopyroxene porphyroclasts, we suppose that the MM1 metasomatic process was an earlier event relative to the entrapment of both fluid inclusion types (Fig. 6).

There were two magmatic pulses in the RGR related to early rifting between 37-15 Ma and late rifting between 15$0 \mathrm{Ma}$ (Baldridge et al., 1980). These magmatic pulses are closely associated with two metasomatic events beneath the Adam's Diggings (Fig. 6): MM2, which was triggered by dehydration melting of hydrous minerals (possibly phlogopite), and MM3, which involved infiltration of the host alkali-basaltic to basanitic melt (Kil \& Wendlandt, 2007). During early rifting with a magmatic pulse (heating; MM2 metasomatic event), deformation (porphyroclastic) textures were developed in response to changes of pressure and temperature conditions in the thinning lithosphere (Kil \& Wendlandt, 2007; Park et al., 2014).

Probably after the MM2 and deformation process, Type$1 \mathrm{FI}\left(\mathrm{CO}_{2}-\mathrm{N}_{2}\right)$ may have been trapped before or during formation of exsolution lamellae (Fig. 6b). Based on the study of mantle xenoliths from the Cameroon Volcanic Line (Pintér et al., 2015), lamellae formation is controlled by the thermal relaxation following extension and thus thinning of the mantle lithosphere. A similar controlling factor is also plausible for the xenoliths studied here, given that the entire lithosphere beneath the RGR preserves a large-scale cooling history, which is partly due to the thermal relaxation of isotherms associated with extension (e.g., Ricketts et al., 2016).

The Type- 1 fluid is unlikely to have a metasomatic effect because there is no evidence for $\mathrm{H}_{2} \mathrm{O}$, silicate melt, or chlorine, which are all known to be capable of dissolving and transporting trace elements at mantle depth (e.g., O'Reilly \& Griffin, 2012).

In contrast, Type-2 FIs can be regarded as a potential source of metasomatism, because Type-2 FIs contain both $\mathrm{H}_{2} \mathrm{O}$ and silicate glass (formerly dissolved melt component, Fig. 5e) possibly representing the fluid-rich part of a precedent silicate melt/fluid immiscibility (see Section 8.4). After the cooling process, MM3 metasomatism was recorded (Kil \& Wendlandt, 2007; Park et al., 2014). Therefore, during the MM3 metasomatism, COHS-rich fluid could have been liberated through melt/fluid immiscibility and trapped as Type-2 FI (Fig. 6c).

\subsection{Post-entrapment reactions within inclusions}

Magnesite and quartz in the Type-1 FIs (Fig. 5a and b) and Mg-carbonate and talc in the Type-2 FIs (Fig. 5c and d) were observed only within the inclusions in the studied xenoliths. Therefore, these solids may likely be considered as "step-daughter crystals" (Scambelluri \& Philippot, 2001) originating from a post-entrapment carbonation reaction between the trapped $\mathrm{CO}_{2}$-rich fluid and the host orthopyroxene (Berkesi et al., 2012; Frezzotti et al., 


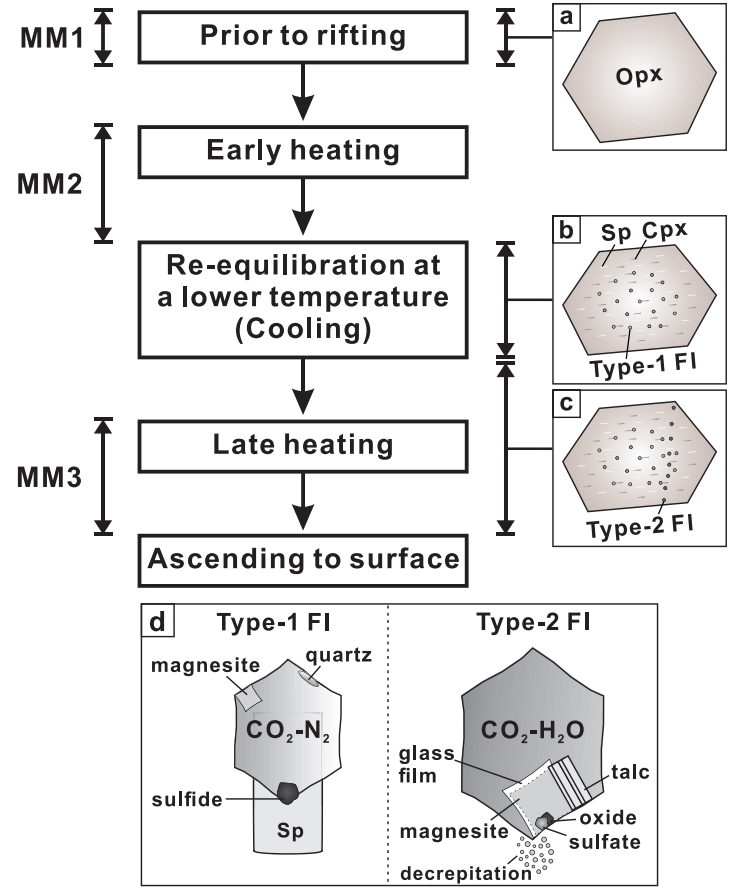

Fig. 6. Possible scenario of fluid invasions related to metasomatic events and thermal history beneath the Adam's Diggings. (a) Protogranular (non-deformed) orthopyroxene grain which has experienced MM1 event prior to rifting. (b) After MM2 and possibly simultaneous deformation process (Kil \& Wendlandt, 2004; Park et al., 2014), Type-1 FIs are entrapped before or during formation of exsolution lamellae (induced by cooling). (c) After cooling, Type-2 FIs are trapped related to MM3 event. (d) Schematic drawing of room-temperature phase relations of both FI generations (Type-1 and 2). MM1-MM3: three mantle metasomatic events in the Adam's Diggings (Kil \& Wendlandt, 2007); Opx, orthopyroxene; $\mathrm{Sp}$, spinel lamellae; Cpx, clinopyroxene lamellae; FI, fluid inclusion. For details, see text. (Online version in color.)

2012a) by one of the two following reactions:

$$
\begin{aligned}
& \mathrm{MgSiO}_{3} \text { (orthopyroxene) }+\mathrm{CO}_{2} \text { (fluid) } \\
& \left.\quad=\mathrm{MgCO}_{3} \text { (magnesite }\right)+\mathrm{SiO}_{2} \text { (quartz) }
\end{aligned}
$$

$$
\begin{aligned}
& 4 \mathrm{MgSiO}_{3} \text { (orthopyroxene) }+\mathrm{CO}_{2} \text { (fluid) }+\mathrm{H}_{2} \mathrm{O} \text { (fluid) } \\
& =\mathrm{Mg}_{3} \mathrm{Si}_{4} \mathrm{O}_{10}(\mathrm{OH})_{2}(\text { talc })+\mathrm{MgCO}_{3} \text { (magnesite) }
\end{aligned}
$$

These carbonation reactions occur at temperatures below $\sim 700-600{ }^{\circ} \mathrm{C}$ for variable pressures (Berkesi et al., 2012; Frezzotti et al., 2012a). The type of reaction products is influenced by the $\mathrm{H}_{2} \mathrm{O}$ content of the trapped fluid, and the $P-T$ conditions of eruption (Frezzotti et al., 2012a). Type-1 and Type-2 FIs must have experienced the same eruption conditions but Type-2 FIs show clear evidence for decrepitation, in contrast to Type-1 F1s (Fig. 2). Larger Type-2 inclusions decrepitate easier and this could result in decreased fluid density within the inclusion cavity that enables talc to precipitate. By whatever mechanism, the occurrence of talc in Type-2 FIs indicates minimum $X_{\mathrm{H}_{2} \mathrm{O}}$ of about 0.3 (Frezzotti et al., 2012a). We assume lower $X_{\mathrm{H}_{2} \mathrm{O}}$ for Type- 1 as no evidence of $\mathrm{H}_{2} \mathrm{O}$ was found.

\section{Concluding summary}

Fluid inclusions in mantle xenoliths from the western margin of RGR (Adam's Diggins) have been carefully investigated to understand the origin and composition of percolating fluids at mantle depth. Two distinct generations of fluid inclusion (Type-1 and Type-2), both entrapped in orthopyroxene porphyroclasts at different time, revealed the compositional heterogeneity of percolating fluids. Type-1 FIs (C-O-N-S) were trapped from an earlier fluid percolation stage, before or during a cooling event that might have been related to the thermal relaxation after lithosphere thinning. Type-2 FIs $(\mathrm{C}-\mathrm{O}-\mathrm{H}-\mathrm{S})$ represent later-stage fluid infiltration likely related to the latest metasomatic event recorded in the xenoliths. Overall, this study provides a better insight to understand the relationship between multiple fluid infiltrations and metasomatic events in the lithospheric mantle beneath the RGR.

Acknowledgements: The authors would like to thank Csaba Szabó for his support and helpful discussions. We thank both Gábor Varga and Kitti Ratter (Faculty of Science Research and Instrument Core Facility of Eötvös University, Hungary) for the FIB-SEM analyses. Careful review of Doug Smith and an anonymous reviewer as well as the editorial handling (Elisabetta Rampone) helped to greatly improve the manuscript. This study was supported by the Mid-career Research Program through NRF grants to Haemyeong Jung funded by the MEST (NRF 2017R1A2B2004688), the Fellowship for Fundamental Academic Fields in Seoul National University to Munjae Park, the Bolyai Postdoctoral Fellowship Program and the Hungarian Scientific Research Fund (Project No. 105410) to Marta Berkesi. Munjae Park was also supported by joint research work between Seoul National University (NRF 2015R1A2A1A15052305) and Eötvös University (funded by TÁMOP-4.2.1/B-09/1/KMK-2010-0003).

\section{References}

Andersen, T. \& Neumann, E.R. (2001): Fluid inclusions in mantle xenoliths. Lithos, 55, 301-320.

Andersen, T., O'Reilly, S.Y., Griffin, W.L. (1984): The trapped fluid phase in upper mantle xenoliths from Victoria, Australia: implications for mantle metasomatism. Contrib. Mineral. Petrol., 88, 72-85.

Andersen, T., Burke, E.A.J., Neumann, E.R. (1995): Nitrogen-rich fluid in the upper mantle: fluid inclusions in spinel dunite from Lanzarote, Canary Islands. Contrib. Mineral. Petrol., 120, 20-28.

Bakker, R.J. (2003): Package FLUIDS 1. Computer programs for analysis of fluid inclusion data and for modelling bulk fluid properties. Chem. Geol., 194, 3-23.

Baldridge, W.S., Damon, P.E., Shafiqullah, M., Bridwell, R.J. (1980): Evolution of the central Rio Grande rift, New Mexico: new potassium-argon ages. Earth Planet. Sci. Lett., 51, 309-321.

Ballhaus, C., Berry, R.F., Green, D.H. (1991): High pressure experimental calibration of the olivine-orthopyroxene-spinel oxygen geobarometer: implications for the oxidation state of the upper mantle. Contrib. Mineral. Petrol., 107, 27-40. 
Bedini, R.M., Bodinier, J.L., Dautria, J.M., Morten, L. (1997): Evolution of LILE-enriched small melt fractions in the lithospheric mantle: a case study from the East African Rift. Earth Planet. Sci. Lett., 153, 67-83.

Belkin, H.E. \& De Vivo, B. (1989): Glass, phlogopite, and apatite in spinel peridotite xenoliths from Sardinia (Italy): evidence for mantle metasomatism. New Mexico Bureau Mines and Mineralogy Research Bulletin 131, 20 p.

Bergman, S.C. \& Dubessy, J. (1984): $\mathrm{CO}_{2}-\mathrm{CO}$ fluid inclusions in a composite peridotite xenolith: implications for upper mantle oxygen fugacity. Contrib. Mineral. Petrol., 85, 1-13.

Berkesi, M., Hidas, K., Guzmics, T., Dubessy, J., Bodnar, R.J., Szabó, C., Vajna, B., Tsunogae, T. (2009): Detection of small amounts of $\mathrm{H}_{2} \mathrm{O}$ in $\mathrm{CO}_{2}$-rich fluid inclusions using Raman spectroscopy. J. Raman Spectrosc., 40, 1461-1463.

Berkesi, M., Guzmics, T., Szabó, C., Dubessy, J., Bodnar, R.J., Hidas, K., Ratter, K. (2012): The role of $\mathrm{CO}_{2}$-rich fluids in trace element transport and metasomatism in the lithospheric mantle beneath the Central Pannonian Basin, Hungary, based on fluid inclusions in mantle xenoliths. Earth Planet. Sci. Lett., 331-332, 8-20.

Berkesi, M., Káldos, R., Park, M., Szabó, C., Váczi, T., Török, K., Németh, B., Czuppon, G. (2017): Detection of small amounts of $\mathrm{N}_{2}$ in $\mathrm{CO}_{2}$-rich high-density fluid inclusions in mantle xenoliths. Eur. J. Mineral., 29, doi:10.1127/ejm/2017/0029-2615.

Bodnar, R.J., Binns, P.R., Hall, D.L. (1989): Synthetic fluid inclusions - VI. Quantitative evaluation of the decrepitation behaviour of fluid inclusions in quartz at one atmosphere confining pressure. J. Metamorph. Geol., 7, 229-242.

Brey, G.P. \& Köhler, T. (1990): Geothermobarometry in four-phase lherzolites II. New thermobarometers, and practical assessment of existing thermobarometers. J. Petrol., 31, 1353-1378.

Byerly, B.L. \& Lassiter, J.C. (2012): Evidence from mantle xenoliths for lithosphere removal beneath the central Rio Grande Rift. Earth Planet. Sci. Lett., 355-356, 82-93.

_, - (2015): Trace element partitioning and Lu-Hf isotope systematics in spinel peridotites from the Rio Grande Rift and Colorado Plateau: towards improved age assessment of clinopyroxene Lu/Hf- ${ }^{176} \mathrm{Hf} /{ }^{177} \mathrm{Hf}$ in SCLM peridotite. Chem. Geol., 413, 146-158.

Campione, M., Malaspina, N., Frezzotti, M.L. (2015): Threshold size for fluid inclusion decrepitation. J. Geophys. Res. Solid Earth, 120, 7396-7402.

Copeland, P., Murphy, M.A., Dupré, W.R., Lapen, T.J. (2011): Oligocene Laramide deformation in southern New Mexico and its implications for Farallon plate geodynamics. Geosphere, 7, 1209-1219.

Dawson, J.B. \& Powell, D.G. (1969): Mica in the upper mantle. Contrib. Mineral. Petrol., 22, 233-237.

Dawson, J.B. \& Smith, J.V. (1982): Upper-mantle amphiboles: a review. Mineral. Mag., 45, 35-46.

Dégi, J., Abart, R., Török, K., Rhede, D., Petrishcheva, E. (2009): Evidence for xenolith-host basalt interaction from chemical patterns in Fe-Ti-oxides from mafic granulite xenoliths of the Bakony-Balaton Volcanic field (W-Hungary). Mineral. Petrol., 95, 219-234.

Dickinson, W.R. \& Snyder, W.S. (1978): Plate tectonics of the Laramide orogeny. Geol. Soc. Am. Memoirs, 151, 355-366.

Frey, F.A. \& Prinz, M. (1978): Ultramafic inclusions from San Carlos, Arizona: petrologic and geochemical data bearing on their petrogenesis. Earth Planet. Sci. Lett., 38, 129-176.
Frezzotti, M.L. (2001): Silicate-melt inclusions in magmatic rocks: applications to petrology. Lithos, 55, 273-299.

Frezzotti, M.-L. \& Touret, J.L.R. (2014): $\mathrm{CO}_{2}$, carbonate-rich melts, and brines in the mantle. Geosci. Front., 5, 697-710.

Frezzotti, M.L., Andersen, T., Neumann, E.R., Simonsen, S.L. (2002): Carbonatite melt- $\mathrm{CO}_{2}$ fluid inclusions in mantle xenoliths from Tenerife, Canary Islands: a story of trapping, immiscibility and fluid-rock interaction in the upper mantle. Lithos, 64, 77-96.

Frezzotti, M.L., Ferrando, S., Peccerillo, A., Petrelli, M., Tecce, F., Perucchi, A. (2010): Chlorine-rich metasomatic $\mathrm{H}_{2} \mathrm{O}-\mathrm{CO}_{2}$ fluids in amphibole-bearing peridotites from Injibara (Lake Tana region, Ethiopian plateau): nature and evolution of volatiles in the mantle of a region of continental flood basalts. Geochim. Cosmochim. Acta, 74, 3023-3039.

Frezzotti, M.L., Ferrando, S., Tecce, F., Castelli, D. (2012a): Water content and nature of solutes in shallow-mantle fluids from fluid inclusions. Earth Planet. Sci. Lett., 351-352, 70-83.

Frezzotti, M.L., Tecce, F., Casagli, A. (2012b): Raman spectroscopy for fluid inclusion analysis. J. Geochem. Explor., 112, 1-20.

Gasparik, T. (2000): An internally consistent thermodynamic model for the system $\mathrm{CaO}-\mathrm{MgO}-\mathrm{Al}_{2} \mathrm{O}_{3}-\mathrm{SiO}_{2}$ derived primarily from phase equilibrium data. J. Geol., 108, 103-119.

Gibson, S.A., Thompson, R.N., Leat, P.T., Morrison, M.A., Hendry, G.L., Dickin, A.P., Mitchell, J.G. (1993): Ultrapotassic Magmas along the Flanks of the Oligo-Miocene Rio Grande Rift, USA: Monitors of the Zone of Lithospheric Mantle Extension and Thinning Beneath a Continental Rift. J. Petrol., 34, 187-228.

Hall, D.L. \& Bodnar, R.J. (1989): Comparison of fluid inclusion decrepitation and acoustic emission profiles of Westerly granite and Sioux quartzite. Tectonophysics, 168, 283-296.

Hidas, K., Guzmics, T., Szabó, C., Kovács, I., Bodnar, R.J., Zajacz, Z., Nédli, Z., Vaccari, L., Perucchi, A. (2010): Coexisting silicate melt inclusions and $\mathrm{H}_{2} \mathrm{O}$-bearing, $\mathrm{CO}_{2}$-rich fluid inclusions in mantle peridotite xenoliths from the CarpathianPannonian region (central Hungary). Chem. Geol., 274, 1-18.

Holloway, J.R. \& Blank, J.G. (1994): Application of experimental results to $\mathrm{COH}$ species in natural melts. Rev. Mineral. Geochem., 30, 187-230.

Hudson, M.R. \& Grauch, V.J.S. (2013): New perspectives on Rio Grande Rift basins: from tectonics to groundwater (introduction). Geological Society of America Special Papers 494, v-xii.

Humphreys, E. (2009): Relation of flat subduction to magmatism and deformation in the western United States. Geol. Soc. Am. Memoirs, 204, 85-98.

Humphreys, E., Hessler, E., Dueker, K., Farmer, G.L., Erslev, E., Atwater, T. (2003): How laramide-age hydration of North American lithosphere by the Farallon slab controlled subsequent activity in the western United States. Int. Geol. Rev., 45, 575-595.

Huraiova, M., Dubessy, J., Konecny, P. (1991): Composition and oxidation state of upper mantle fluids from southern Slovakia. Plinius, 5, 110-111.

Izraeli, E.S., Harris, J.W., Navon, O. (2001): Brine inclusions in diamonds: a new upper mantle fluid. Earth Planet. Sci. Lett., 187, 323-332.

Kawamoto, T., Yoshikawa, M., Kumagai, Y., Mirabueno, M.H.T., Okuno, M., Kobayashi, T. (2013): Mantle wedge infiltrated with saline fluids from dehydration and decarbonation of subducting slab. Proc. Natl. Acad. Sci., 110, 9663-9668. 
Kil, Y. \& Wendlandt, R.F. (2004): Pressure and temperature evolution of upper mantle under the Rio Grande rift. Contrib. Mineral. Petrol., 148, 265-280.

_, - (2007): Depleted and enriched mantle processes under the Rio Grande rift: spinel peridotite xenoliths. Contrib. Mineral. Petrol., 154, 135-151.

Konzett, J., Krenn, K., Rubatto, D., Hauzenberger, C., Stalder, R. (2014): The formation of saline mantle fluids by open-system crystallization of hydrous silicate-rich vein assemblages evidence from fluid inclusions and their host phases in MARID xenoliths from the central Kaapvaal Craton, South Africa. Geochim. Cosmochim. Acta, 147, 1-25.

Kyser, T.K. \& Rison, W. (1982): Systematics of rare gas isotopes in basic lavas and ultramafic xenoliths. J. Geophys. Res. Solid Earth, 87, 5611-5630.

Lee, C.T.A. (2005): Trace element evidence for hydrous metasomatism at the base of the North American lithosphere and possible association with Laramide low-angle subduction. $J$. Geol., 113, 673-685.

Leeman, W.P. (1982): Tectonic and magmatic significance of strontium isotopic variations in Cenozoic volcanic rocks from the western United States. Geol. Soc. Am. Bull., 93, 487-503.

McCallister, R.H. \& Yund, R.A. (1977): Coherent exsolution in Fefree pyroxenes. Am. Mineral., 62, 721-726.

Menzies, M., Rogers, N., Tindell, A., Hawkesworth, C. (1987): Metasomatic and enrichment processes in lithospheric peridotites, an effect of asthenosphere-lithosphere. in "Mantle metasomatism: monograph series". Academic Press, UK, 312-364.

Murck, B., Burruss, R., Hollister, L. (1978): Phase equilibria in fluid inclusions in ultramafic xenoliths. Am. Mineral., 63, 40-46.

Nimis, P. \& Grütter, H. (2010): Internally consistent geothermometers for garnet peridotites and pyroxenites. Contrib. Mineral. Petrol., 159, 411-427.

O'Reilly, S.Y. \& Griffin, W.L. (2000): Apatite in the mantle: implications for metasomatic processes and high heat production in Phanerozoic mantle. Lithos, 53, 217-232.

Park, M., Jung, H., Kil, Y. (2014): Petrofabrics of olivine in a rift axis and rift shoulder and their implications for seismic anisotropy beneath the Rio Grande rift. Island Arc, 23, 299-311.

Pasteris, J.D. (1987): Fluid inclusions in mantle xenoliths. in "Mantle xenoliths", 691-707.

Pintér, Z., Patkó, L., Tene Djoukam, J.F., Kovács, I., Tchouankoue, J.P., Falus, G., Konc, Z., Tommasi, A., Barou, F., Mihály, J., Németh, C., Jeffries, T. (2015): Characterization of the subcontinental lithospheric mantle beneath the Cameroon volcanic line inferred from alkaline basalt hosted peridotite xenoliths from Barombi Mbo and Nyos Lakes. J. African Earth Sci., 111, 170-193.

Perry, F.V., Baldridge, W.S., DePaolo, D.J. (1987): Role of asthenosphere and lithosphere in the genesis of Late Cenozoic basaltic rocks from the Rio Grande Rift and adjacent regions of the southwestern United States. J. Geophys. Res.: Solid Earth, 92, 9193-9213.

Porreca, C., Selverstone, J., Samuels, K. (2006): Pyroxenite xenoliths from the Rio Puerco volcanic field, New Mexico: melt metasomatism at the margin of the Rio Grande rift. Geosphere, 2, 333-351.

Putnis, A. (1992): An introduction to mineral sciences. Cambridge University Press.
Ricketts, J.W., Kelley, S.A., Karlstrom, K.E., Schmandt, B., Donahue, M.S., van Wijk, J. (2016): Synchronous opening of the Rio Grande rift along its entire length at 25-10 Ma supported by apatite (U-Th)/He and fission-track thermochronology, and evaluation of possible driving mechanisms. Geol. Soc. Am. Bull., 128, 397-424.

Roden, M.F., Irving, A.J., Murthy, V.R. (1988): Isotopic and trace element composition of the upper mantle beneath a young continental rift: results from Kilbourne Hole, New Mexico. Geochim. Cosmochim. Acta, 52, 461-473.

Roedder, E. (1965): Liquid $\mathrm{CO}_{2}$ inclusions in olivine-bearing nodules and phenocrysts from basalts. Am. Mineral., 50, 1746-1782.

- (1984): Fluid inclusions. Rev. Mineral., 12, 1-646.

Rowe, M.C. \& Lassiter, J.C. (2009): Chlorine enrichment in central Rio Grande Rift basaltic melt inclusions: evidence for subduction modification of the lithospheric mantle. Geology, 37, 439-442.

Rowe, M.C., Lassiter, J.C., Goff, K. (2015): Basalt volatile fluctuations during continental rifting: an example from the Rio Grande Rift, USA. Geochem. Geophys. Geosyst., 16, 1254-1273.

Sachan, H.K., Mukherjee, B.K., Bodnar, R.J. (2007): Preservation of methane generated during serpentinization of upper mantle rocks: evidence from fluid inclusions in the Nidar ophiolite, Indus Suture Zone, Ladakh (India). Earth Planet. Sci. Lett., 257, 47-59.

Sánchez-Muñoz, L., del Campo, A., Fernández, J.F. (2016): Symmetry constraints during the development of anisotropic spinodal patterns. Scient. Rep., 6, 20806.

Scambelluri, M. \& Philippot, P. (2001): Deep fluids in subduction zones. Lithos, 55, 213-227.

Schiano, P. \& Clocchiatti, R. (1994): Worldwide occurrence of silica-rich melts in sub-continental and sub-oceanic mantle minerals. Nature, 368, 621-624.

Schiano, P., Clocchiatti, R., Joron, J.L. (1992): Melt and fluid inclusions in basalts and xenoliths from Tahaa Island, Society archipelago: evidence for a metasomatized upper mantle. Earth Planet. Sci. Lett., 111, 69-82.

Severinghaus, J. \& Atwater, T. (1990): Cenozoic geometry and thermal state of the subducting slabs beneath western North America. Geol. Soc. Am. Memoirs, 176, 1-22.

Smith, D. (2000): Insights into the evolution of the uppermost continental mantle from xenolith localities on and near the Colorado Plateau and regional comparisons. J. Geophys. Res. Solid Earth, 105, 16769-16781.

Smith, D., Riter, J.C.A., Mertzman, S.A. (1999): Water-rock interactions, orthopyroxene growth, and Si-enrichment in the mantle: evidence in xenoliths from the Colorado Plateau, southwestern United States. Earth Planet. Sci. Lett., 165, 45-54.

Span, R. \& Wagner, W. (1996): A New Equation of State for Carbon Dioxide Covering the Fluid Region from the Triple Point Temperature to $1100 \mathrm{~K}$ at Pressures up to $800 \mathrm{MPa}$. J. Phys. Chem. Ref. Data, 25, 1509-1596.

Spengler, D., Obata, M., Hirajima, T., Ottolini, L., Ohfuji, H., Tamura, A., Arai, S. (2012): Exsolution of garnet and clinopyroxene from high-Al pyroxenes in Xugou Peridotite, Eastern China. J. Petrol., 53, 1477-1504.

Szabó, C. \& Bodnar, R.J. (1996): Changing magma ascent rates in the Nógrád-Gömör volcanic field Northern Hungary/Southern Slovakia: evidence from $\mathrm{CO}_{2}$-rich fluid inclusions in metasomatized upper mantle xenoliths. Petrology, 4, 221-230. 
Szabó, C., Hidas, K., Bali, E., Zajacz, Z., Kovács, I., Yang, K., Guzmics, T., Török, K. (2009): Melt-wall rock interaction in the mantle shown by silicate melt inclusions in peridotite xenoliths from the central Pannonian Basin (western Hungary). Island Arc, 18, 375-400.

Taylor, W.R. \& Green, D.H. (1988): Measurement of reduced peridotite- $\mathrm{COH}$ solidus and implications for redox melting of the mantle. Nature, 332, 349-352.

Török, K. \& De Vivo, B. (1995): Fluid inclusions in upper mantle xenoliths from the Balaton Highland, Western Hungary. Acta Vulcanol., 7, 277-284.

van den Kerkhof, A.M. (1988): The system $\mathrm{CO}_{2}-\mathrm{CH}_{4}-\mathrm{N}_{2}$ in fluid inclusions: theoretical modelling and geological applications. Ph.D. Dissertation, Free University, Amsterdam, 209 p.

Van den Kerkhof, A.M. \& Hein, U.F. (2001): Fluid inclusion petrography. Lithos, 55, 27-47.

Viti, C. \& Frezzotti, M.L. (2000): Re-equilibration of glass and $\mathrm{CO}_{2}$ inclusions in xenolith olivine: a TEM study. Am. Mineral., 85, 1390-1396.

Wanamaker, B.J. \& Evans, B. (1989): Mechanical re-equilibration of fluid inclusions in San Carlos olivine by power-law creep. Contrib. Mineral. Petrol., 102, 102-111.
Watenphul, A., Wunder, B., Wirth, R., Heinrich, W. (2010): Ammonium-bearing clinopyroxene: A potential nitrogen reservoir in the Earth's mantle. Chem. Geol., 270, 240-248.

Wyllie, P.J. \& Ryabchikov, I.D. (2000): Volatile components, magmas, and critical fluids in upwelling mantle. J. Petrol., 41, 1195-1206.

Yamamoto, J., Kagi, H., Kaneoka, I., Lai, Y., Prikhod'ko, V.S., Arai, S. (2002): Fossil pressures of fluid inclusions in mantle xenoliths exhibiting rheology of mantle minerals: implications for the geobarometry of mantle minerals using micro-Raman spectroscopy. Earth Planet. Sci. Lett., 198, 511-519.

Yamamoto, J., Otsuka, K., Ohfuji, H., Ishibashi, H., Hirano, N., Kagi, H. (2011): Retentivity of $\mathrm{CO}_{2}$ in fluid inclusions in mantle minerals. Eur. J. Mineral., 23, 805-815.

Received 2 October 2016

Modified version received 1 February 2017

Accepted 29 March 2017 